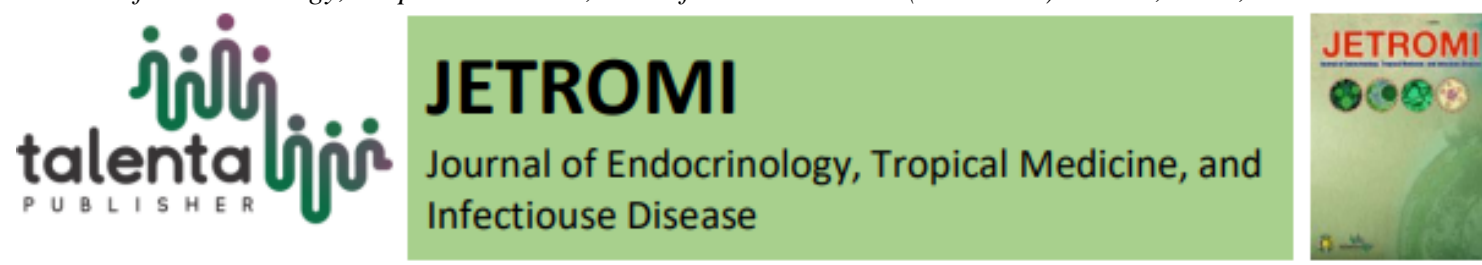

\title{
Relationship Between BMI Degree and Non-Alcoholic Fatty Liver Disease Risk Factors
}

\author{
Chairunnisa Fitri Marpaung ${ }^{1}$, Gontar Alamsyah Siregar ${ }^{2}$, Ilhamd ${ }^{2}$ \\ ${ }^{1}$ Department of Internal Medicine, Faculty of Medicine, University of Sumatera Utara, Medan, North \\ Sumatera, Indonesia \\ ${ }^{2}$ Division of Gastroenterology, Department of Internal Medicine, Faculty of Medicine, Universitas Sumatera \\ Utara
}

\begin{abstract}
Background: Obesity is a major risk factor for cardiovascular disease, type 2 diabetes, high blood pressure, sleep apnea, psychological issues, some musculoskeletal conditions, and some cancers. The aim of the study to evaluate the correlation between BMI and risk factor of non-alcoholic fatty liver disease (NAFLD). Method: The research was conducted crosssectionally in NAFLD patients who were treated at RSUP H Adam Malik Medan and got approval from the Ethics Commission for Health Research. Sample research is NAFLD patients who are taken in consecutive sampling that meets the criteria of inclusion and exclusion. Body mass index (BMI) is obtained by dividing a person's weight in kilograms by their height in square meters, define obesity (OB) if BMI > 25, overweight (OW) BMI 23-24.9, and normoweight (NW) BMI 18.5-22.9. Diagnose NAFLD by performing ultrasound examination, resistin and adiponectin examination with ELISA (Sandwich Immunoassay), liver function according to IFCC (International Federation of Clinical Chemistry), and albumin checked by BCG method. Result: There were 67 patients $(\mathrm{NM}=32, \mathrm{OW}=15, \mathrm{OB}=20)$ NAFLD with an average age of $42.1 \pm$ 11.9 years, Comparison of NAFLD risk factors in normoweight, overweight, and obesity, showing very significant results (all $\mathrm{p}<0.001$ ). There is a very significant correlation between BMI and all NAFLD risk factors (all $\mathrm{p}<0.001$ ). Conclusion: There are very significant correlates between BMI and all inflammatory factors of NAFLD.
\end{abstract}

Keyword: BMI, NAFLD risk factors

\begin{abstract}
Abstrak. Latar Belakang : Obesitas adalah faktor risiko utama untuk penyakit kardiovaskular, Diabetes tipe 2, tekanan darah tinggi, apnoea waktu tidur, masalah psikologis, beberapa kondisi muskuloskeletal dan kanker. Tujuan penelitian untuk mengevaluasi korelasi antara BMI dan faktor risiko non-alcoholic fatty liver disease (NAFLD) Metode: Penelitian dilakukan secara cross sectional pada pasien NAFLD yang dirawat di RSUP H Adam Malik Medan dan mendapat persetujuan dari Komisi Etik Penelitian Kesehatan. Sampel penelitian adalah pasien NAFLD yang diambil consecutive sampling yang memenuhi kriteria inklusi dan ekslusi. Indeks massa tubuh (IMT) diperoleh dengan membagi berat badan dalam kilogram dengan tinggi badan mereka di meter persegi. Definisikan obesitas $(O B)$ jika $I M T>25$, kelebihan berat badan $(O W)$ IMT 23-24,9 dan normoweight (NW) IMT 18,5-22,9. Diagnosa NAFLD dengan melakukan
\end{abstract}

\footnotetext{
*Corresponding author at: Department of Internal Medicine, Faculty of Medicine, University of Sumatera Utara, Medan, North Sumatera, Indonesia

E-mail address: drchairunnisafitri@gmail.com
}

Copyright @ 2021 Published by Talenta Publisher, ISSN: 2686-0872 e-ISSN: 2686-0856 DOI: https://doi.org/10.32734/jetromi.v3i1.5593

Journal Homepage: https://jetromi.usu.ac.id

Attribution-NonCommercial-ShareAlike 4.0 International 
pemeriksaan USG, pemeriksaan resistin dan adiponektin dengan ELISA (Sandwich Immunuassay), fungsi hati menurut IFCC (International Federation of Clinical Chemistry), dan albumin diperiksa dengan metode BCG. Hasil: Terdapat 67 pasien $(N M=32, O W=15, O B=20)$ NAFLD dengan usia rata-rata 42,1 11,9 tahun, Faktor risiko NAFLD pada normoweight, kelebihan berat badan dan obesitas, menunjukan hasil sangat signifikan (semua $P<0.001$ ). Ada korelasi yang sangat signifikan antara IMT dengan faktor semua risiko NAFLD (semua $P<0.001)$. Kesimpulan: Ada korelasi yang sangat signifikan antara IMT dengan semua faktor inflamasi NAFLD.

Kata Kunci: IMT, faktor risiko NAFLD

Received 30 January 2021 | Revised 27 February 2021 | Accepted 28 February 2021

\section{Introduction}

Excessive calorie consumption relative to expenditure, intake of unhealthy diets, and lack of physical activity are globally. [1] Fuelling an increase in the prevalence of poor metabolic health, even in individuals of normal weight. [2] Consequently, this trend entails increased risk of various metabolic disorders, including non-alcoholic fatty liver disease (NAFLD), recently re-named metabolic associated fatty liver disease (MAFLD), which affects about a quarter of the global population. [3]

Non-alcoholic fatty liver disease (NAFLD) represents a condition of excessive accumulation of fat in the liver of people consuming alcohol at amounts below risk levels. [4] The condition may be limited to excessive liver fat (NAFL) or progress to necroinflammation and fibrosis non-alcoholic steatohepatitis (NASH) to NASH-cirrhosis, [5] and eventually to hepatocellular carcinoma. [6]

The prevalence of NAFLD in the general population is about $25 \%$, peaking at more than $30 \%$ in the Middle East and South America and as low as 13\% in Africa. [7] Although NAFLD is associated with metabolic syndrome and obesity rates, [8] a recent meta-analysis of 84 studies (more than 10 million cases) concluded that $40.8 \%$ (95\% confidence interval $36.6 \%$ to $45.1 \%$ ) of patients with NAFLD were non-obese and $19.2 \%(15.9 \%$ to $23.0 \%)$ were definitely lean. [9] These rates were calculated with body mass index (BMI) a djusted for ethnicity that is less than 23 for normal weight and 23.0-27.5 for overweight in Asians.

Increased levels of markers of inflammation such as high sensitivity C-Reactive Protein (hs-CRP), certain interleukins and Tumor Necrosis Factor Alpha (TNF-alpha) have been linked with metabolic disorders, cardiovascular diseases as well as an increased risk of mortality. Obesity also influences the development of these outcomes. Better understanding of the link between weight gain, obesity and the development of low-grade chronic inflammation could prove useful in addressing these major public health issues.

The aim of the study was to analyse whether BMI correlate with parameter risk factors NAFLD. 


\section{Method}

The research was conducted cross sectionally in NAFLD patients who treated at RSUP H Adam Malik Medan and got approval from the Ethics Commission for Health Research. Sample research is NAFLD patients who are taken in consecutive sampling that meets the criteria of inclusion and exclusion. Body mass index (BMI) is obtained by dividing a person's weight in kilograms by their height in square meters, define of obesity (OB) if BMI > 25, overweight (OW) BMI 23-24.9 and normoweight (NW) BMI 18.5-22.9.

Diagnose NAFLD by performing ultrasound examination, resistin and adiponectin examination with ELISA (Sandwich Immunuassay), liver function according to IFCC (International Federation of Clinical Chemistry), and albumin checked by BCG method.

\section{Data Analysis}

Data univariate analysis is presented descriptively, displaying average data and standard deviations. Test normality of data using Shapiro wilk test. Bivariate analysis uses T-independent test if data is distributed normally. If data is not distributed normally used Mann-whitney test. Spearman correlation if data is not distributed normall. Difference in means used test Krusla wallis Analysis using computer programs SPSS 23 (Statistical Product and for Social Sciences) and confidence intervals of $95 \%$, where $\mathrm{p}<0.05$.

\section{Results}

In table 1, there were 67 NAFLD patients with an average age of $42.1 \pm 11.9$ years,

Table 1 Baseline data of NFLD Patients

\begin{tabular}{lc}
\hline Parameters & $\mathbf{n = 6 7}$, mean \pm SD \\
\hline BMI Kg/M & $24.02 \pm 3.7$ \\
RBS $\mathrm{mg} / \mathrm{dL}$ & $210.1 \pm 83.8$ \\
SGOT $\mu / \mathrm{l}$ & $58.9 \pm 26.9$ \\
SGPT $\mu / \mathrm{l}$ & $40.3 \pm 9.1$ \\
Trombosit $10^{3} / \mu \mathrm{L}$ & $220089.5 \pm 85777.8$ \\
Albumin $\mathrm{mg} / \mathrm{dL}$ & $3.3 \pm 0.5$ \\
Adiponektin $\mu \mathrm{g} / \mathrm{mL}$ & $7.1 \pm 2.3$ \\
Resistin $\mathrm{ng} / \mathrm{mL}$ & $3.1 \pm 0.9$ \\
\hline
\end{tabular}

In table 2, comparison of NAFLD risk factors in normoweight, overweight and obesity, showed very significant $\mathrm{P}<0.001$ results 
Table 2 Comparison of NFLD Risk Factors to Nutrition Status

\begin{tabular}{lcccc}
\hline \multicolumn{1}{c}{ Parameters } & $\begin{array}{c}\text { NW } \\
(\mathrm{n}=32, \text { mean } \pm \text { SD })\end{array}$ & $\begin{array}{c}\text { OW } \\
(\mathrm{n}=15, \text { mean } \pm \mathrm{SD})\end{array}$ & $\begin{array}{c}\text { OB } \\
(\mathrm{n}=20, \text { mean } \pm S D)\end{array}$ & $\mathbf{p}$ \\
\hline BMl Kg/M & $20.8 \pm 1.1$ & $24.8 \pm 2.4$ & $28.5 \pm 1.7$ & 0.001 \\
$\mathrm{RBS} \mathrm{mg} / \mathrm{dL}$ & $148.3 \pm 59.7$ & $268.2 \pm 61.2$ & $265.3 \pm 59.5$ & 0.001 \\
SGOT $\mu / \mathrm{l}$ & $39.5 \pm 13.9$ & $62.4 \pm 20.0$ & $87.3 \pm 20.1$ & 0.001 \\
SGPT $\mu / \mathrm{l}$ & $35.8 \pm 7.2$ & $41.4 \pm 7.6$ & $46.8 \pm 9.1$ & 0.001 \\
Trombosit $10^{3} / \mu \mathrm{L}$ & $289875.0 \pm 60748.9$ & $191133.3 \pm 27310.0$ & $130150.0 \pm 9.1$ & 0.001 \\
Albumin $\mathrm{mg} / \mathrm{dL}$ & $3.8 \pm 0.4$ & $3.1 \pm 0.2$ & $2.8 \pm 0.2$ & 0.001 \\
Adiponektin $\mu \mathrm{g} / \mathrm{mL}$ & $8.2 \pm 1.9$ & $7.1 \pm 1.7$ & $5.3 \pm 2.3$ & 0.001 \\
Resistin $\mathrm{ng} / \mathrm{mL}$ & $2.7 \pm 0.6$ & $2.9 \pm 0.8$ & $3.8 \pm 0.9$ & 0.001 \\
\hline
\end{tabular}

In table 3, there is a very significant correlation between BMI and all NAFLD risk factors

Table 3 The Relationship between BMI and NAFLD risk factors

\begin{tabular}{lcc}
\hline \multicolumn{1}{c}{ Parameters } & r & p \\
\hline RBS $\mathrm{mg} / \mathrm{dL}$ & $0.669^{* *}$ & 0.001 \\
SGOT $\mu / \mathrm{l}$ & $0.840^{* *}$ & 0.001 \\
SGPT $\mu / \mathrm{l}$ & $0.662^{* *}$ & 0.001 \\
Trombosit $10^{3} / \mu \mathrm{L}$ & $-0.869^{* *}$ & 0.001 \\
Albumin $\mathrm{mg} / \mathrm{dL}$ & $-0.871^{* *}$ & 0.001 \\
Adiponektin $\mu \mathrm{g} / \mathrm{mL}$ & $-0.583^{* *}$ & 0.001 \\
Resistin $\mathrm{ng} / \mathrm{mL}$ & $0.457^{* *}$ & 0.001 \\
\hline
\end{tabular}

\section{Discussion}

The earliest events initiating NAFLD reside in an absolute or relative calorie excess, as confirmed by the link between NAFLD and obesity. Limited physical activity, sedentary behaviors, and screen watching are complementary aspects of calorie imbalance irrespective of BMI. [10] Increased substrate flux will overload adipose tissue compartments, leading to dysfunctional adipose tissue, a spillover of free fatty acids into non-adipose tissues, de novo lipogenesis, and accumulation of lipids in the liver. This process has been described by Unger as "lipotoxicity". [11] Progression of liver disease is extremely variable; pure fatty liver (NAFL) does not reduce life expectancy, whereas patients with NASH have increased all-cause and liver-related mortality. [12] Liver biopsy remains the sole method for correct disease classification, but guidelines suggest limiting its use to very specific settings. The NAFLD activity score, calculated as the sum of steatosis (0-3), lobular inflammation (0-3), and hepatocellular ballooning (0-2), is largely used, but the European SAF (Steatosis, Activity, Fibrosis) score more precisely identifies the components of disease progression. [13] Fibrosis is the most ominous predicting factor; it increases on average by one stage over 14.3 years in patients with NAFL and 7.1 years in patients with NASH. [14] The whole cardiovascular system is often involved, driven by the atherogenic profile and features of metabolic syndrome. [15] Cardiovascular disease remains the most common cause of death [16]; diffuse atherogenic lesions, 
such as coronary artery disease and increased carotid intima-media thickness, [17] are more common in NAFLD, independent of traditional risk factors. Left ventricular failure and altered cardiac energy metabolism have also been described. [18] NAFLD doubled the risk of incident type 2 diabetes in a meta-analysis incorporating data from 20 observational studies (nearly 117000 people without diabetes), over a median five-year follow-up. [19] The risk is diminished by resolution of NAFLD, [20] pointing to the accumulation of liver fat as a cofactor in the pathogenesis of type 2 diabetes. [21] Obese individuals have a 3.5-fold increased risk of developing NAFLD, and there is an obvious dosedependent relationship between BMI and NAFLD risk.[22] Individuals with fatty liver, even if they were not overweight, are probably complicated by the risk of metabolic syndrome, that is, a fatty liver per se also has clinical significance. However, since these pathological findings were also dependent on BMI. [23]. In this study there was a difference between the risk factor of NAFLD at each level of BMI, and BMI correlated significantly with the risk factor NAFLD.

\section{Conclusion:}

There are very significant correlates between BMI and all inflamatori factors of NFLD.

\section{REFERENCES}

[1] Inoue Y, Qin B, Poti J, Sokol R, Gordon-Larsen P. , "Epidemiology of obesity in adults: latest trends.," Curr Obes Rep, vol. ; 7: p. 276-88, 2018.

[2] Stefan N, Schick F, Haring HU, "Causes, characteristics, and consequences of metabolically unhealthy normal weight in humans.," Cell Metab , vol. ; 26: , p. 292-300, 2017.

[3] Younossi Z, Anstee QM, Marietti M, et al. , "Global burden of NAFLD and NASH: trends, predictions, risk factors and prevention.," Nat Rev Gastroenterol Hepatol , vol. ; 15:, p. 11-20, 2018.

[4] Ludwig J, Viggiano TR, McGill DB, Oh BJ., "Nonalcoholic steatohepatitis: Mayo Clinic experiences with a hitherto unnamed disease.," Mayo Clin Proc, vol. ;55: pp. 434-8. 1980.

[5] Hui JM, Kench JG, Chitturi S, et al. "Long-term outcomes of cirrhosis in nonalcoholic steatohepatitis compared with hepatitis C.," Hepatology, vol. ;38: pp. 420-7., 2003 doi:10.1053/jhep.2003.50320.

[6] Bugianesi E, Leone N, Vanni E, et al. "Expanding the natural history of nonalcoholic steatohepatitis: from cryptogenic cirrhosis to hepatocellular carcinoma.," Gastroenterology, vol. ;123:1, pp. 34-40. , 2002 doi:10.1053/gast.2002.34168 .

[7] Younossi ZM, Koenig AB, Abdelatif D, Fazel Y, Henry L, Wymer M. "Global epidemiology of nonalcoholic fatty liver disease-Metaanalytic assessment of prevalence, incidence, and outcomes.," Hepatology, vol. ;64: pp. 73-84. 2016 doi:10.1002/hep.28431 . 
[8] Yki-Järvinen H, "Non-alcoholic fatty liver disease as a cause and a consequence of metabolic syndrome.," Lancet Diabetes Endocrinol, vol. ;2: pp. 901-10. 2014 doi:10.1016/S22138587(14)70032-4.

[9] Ye Q, Zou B, Yeo YH, et al. , "Global prevalence, incidence, and outcomes of non-obese or lean non-alcoholic fatty liver disease: a systematic review and meta-analysis.," Lancet Gastroenterol Hepatol, vol. ;5: pp. 739-52. 2020 doi:10.1016/S2468-1253(20)30077-7.

[10] Croci I, Coombes JS, Bucher Sandbakk S, et al. , "Non-alcoholic fatty liver disease: Prevalence and all-cause mortality according to sedentary behaviour and cardiorespiratory fitness. The HUNT Study.," Prog Cardiovasc Dis , vol. ;62: pp. 127-34., 2019 doi:10.1016/j. pcad.20.

Unger RH. "Lipotoxic diseases.," Аnnu Rev Med , vol ;53:, pp. 319-36., 2002

[11] doi:10.1146/annurev.med.53.082901.104057.

[12] Ekstedt M, Franzén LE, Mathiesen UL, et al. , "Long-term followup of patients with NAFLD and elevated liver enzymes.," Hepatology, vol ;44. pp. :865-73, 2006 doi:10.1002/hep.21327

[13] Bedossa P,, "FLIP Pathology Consortium. Utility and appropriateness of the fatty liver inhibition of progression (FLIP) algorithm and steatosis, activity, and fibrosis (SAF) score in the evaluation of biopsies of nonalcoholic fatty liver disease.," Hepato, vol. ;60:, pp. 565-75, 2014. doi:10.1002/hep.27173 .

[14] Singh S, Allen AM, Wang Z, Prokop LJ, Murad MH, Loomba R. "Fibrosis progression in nonalcoholic fatty liver vs nonalcoholic steatohepatitis: a systematic review and meta-analysis of pairedbiopsy studies.," Clin Gastroenterol Hepatol, vol. ;13: pp. 643-54. 2015.

[15] Stepanova M, Younossi ZM., " Independent association between nonalcoholic fatty liver disease and cardiovascular disease in the US population.," Clin Gastroenterol Hepatol, vol. ;10: , pp. 646-50., 2012 doi:10.1016/j.cgh.2011.12.039.

[16] Sanyal AJ, Harrison SA, Ratziu V, et al. , "The natural history of advanced fibrosis due to nonalcoholic steatohepatitis: Data from the simtuzumab trials.," Hepatology, vol. ;70:, pp. 1913-27., 2019 doi:10.1002/ hep.30664.

[17] Targher G, Day CP, Bonora E. , "Risk of cardiovascular disease in patients with nonalcoholic fatty liver disease.," N Engl J Med, vol. ;363: pp. 1341-50, 2010 doi:10.1056/NEJMra0912063

[18] Lonardo A, Nascimbeni F, Mantovani A, Targher G. , "Hypertension, diabetes, atherosclerosis and NASH: Cause or consequence?," J Hepatol , vol ;68: pp. 335-52., 2018 doi:10.1016/j.jhep.2017.09.021.

[19] Ballestri S, Zona S, Targher G, et al., "Nonalcoholic fatty liver disease is associated with an almost twofold increased risk of incident type 2 diabetes and metabolic syndrome. Evidence from a systematic review and meta-analysis." J Gastroenterol Hepatol, vol. ;31: pp. 936-44, 2016 doi:10.1111/jgh.13264.

[20] Yamazaki H, Tsuboya T, Tsuji K, Dohke M, Maguchi H. , "Independent association between improvement of nonalcoholic fatty liver disease and reduced incidence of type 2 diabetes.," Diabetes Care, vol. ;38, pp. :1673-9., 2015 doi:10.2337/dc15-0140

[21] Taylor R, Al-Mrabeh A, Zhyzhneuskaya S, et al. "Remission of Human Type 2 Diabetes Requires Decrease in Liver and Pancreas Fat Content but Is Dependent upon Capacity for $\beta$ 
Cell Recovery.," Cell Metab, vol. ;28, pp. :547-556.e3., 2018 doi:10.1016/j.cmet.2018.07.003. 2016

[22] Li, L., Liu, D.-W., Yan, H.-Y., Wang, Z.-Y., Zhao, S.-H., \& Wang, B. , "Obesity is an independent risk factor for non-alcoholic fatty liver disease: evidence from a meta-analysis of 21 cohort studies.," Obesity Reviews, , Vols. 17(6), , p. 510-519. doi:10.1111/obr.,

[23] Tadahiko Mitsumunel; Hiroyuki Shimomura2; Etsuo Senoht; and Eizoh Kayashimal , "The Relationship between Risk Factors of Metabolic Syndrome and Fatty Liver Detected Using Ultrasonography," HEP., , Vols. Vol. 30, No. 4,, pp. 433-435, , 2003. 